\title{
Secondary School Mathematics Teachers' Views on E-learning Implementation Barriers during the COVID-19 Pandemic: The Case of Indonesia
}

\author{
Mailizar ${ }^{1 *}$, Abdulsalam Almanthari $^{2}$, Suci Maulina ${ }^{3}$, Sandra Bruce ${ }^{2}$ \\ ${ }^{1}$ Mathematics Education Department, Universitas Syiah Kuala, Banda Aceh, INDONESIA \\ 2 Ibri College of Technology, OMAN \\ ${ }^{3}$ Realistic Mathematics Education Research Centre, Universitas Syiah Kuala, Banda Aceh, INDONESIA
}

Received 13 April 2020 - Accepted 2 May 2020

\begin{abstract}
School closures in Indonesia during the COVID-19 pandemic have left 45.5 million school students and 3.1 million teachers dependent on online teaching and learning. Online teaching and learning are an unprecedented experience for most teachers and students; consequently, they have a limited experience with it. This paper examines the views of secondary school mathematics teachers on E-learning implementation barriers during the COVID-19 pandemic at four barrier levels, namely teacher, school, curriculum and student. Furthermore, it assesses the relationship between barrier levels with teachers' demographic background. Data was collected through an online questionnaire, involving 159 participants from lower and upper secondary schools in Indonesia. The findings of this study suggest that student level barrier had the highest impact on e-learning use. In addition, the student level barrier showed strong positive correlation with the school level barrier and curriculum level barrier. The study showed that teachers' backgrounds had no impact on the level of barriers. This study stimulates further discussion on the way to overcome e-learning barriers whilst simultaneously maximizing benefits of E-learning during this pandemic and beyond it by highlighting the importance of students' voices.
\end{abstract}

Keywords: barrier to e-Learning, e-learning during COVID-19, e-Learning in mathematics education, e-learning in Indonesia

\section{INTRODUCTION}

The World Health Organization (WHO) declared COVID-19 a global emergency on January $30^{\text {th }}, 2020$ and a global pandemic on March 11 th, 2020 . Currently, COVID-19 is affecting 213 countries and territories (WHO, 2020). In response to COVID-19, several countries have applied strict social distancing measures and a lockdown policy. Obviously, this pandemic has had a tremendous impact on schools, students and teachers. As of March 12 $2^{\text {th }}, 2020,46$ countries in five different continents have declared school closures and 26 of these countries have fully closed schools nationwide (Huang, Liu, Tlili, Yang, \& Wang, 2020). In Indonesia, the Government has restricted community mobilization in an attempt to prevent the spread of the disease and keeps promoting an agenda of: work from home, study from home and worship at home. Schools and Higher Education Institutions (HEIs) in Indonesia have been temporarily closed since March 14 $4^{\text {th }}, 2020$.

To deal with schools and HEIs closures in Indonesia, the teaching and learning process has been maintained remotely using Information and Communication Technologies (ICT). Electronic learning (e-learning) has been considered the best possible approach to continue the teaching and learning process during the pandemic. In Indonesia, the e-learning platforms recommended by the government are Rumah Belajar and SPAD. Rumah Belajar is a free online learning platform developed by the Ministry of Education and Culture of Indonesia as an alternative learning resource for school teachers and students. SPADA is an e-learning platform developed by the Ministry of Research, Technology, and Higher Education for HEIs. In addition to that, the Ministry of 


\section{Contribution to the literature}

- This study investigated barriers to e-learning during Covid-19 pandemic, therefore, it enhances to literature regarding challenges of remote learning during this pandemic.

- This study is first empirical study in Indonesia to investigate barriers to use of e-learning in context of the secondary schools during this pandemic.

- Indonesian as a developing country that has the fourth largest education system in the world, the finding of this study has implication not only for Indonesia but also for other developing countries that need to implement e-learning during this pandemic and even beyond it.

Education and Culture of Indonesia partnered with several online learning applications, such as, MejaKita, ICANDO, Ganeca Digital, Kelas Pintar, Quipper School, Ruang Guru, Sekolahmu, Zenius, Cisco Webex, and Pahamify. All these resources support students and teachers so that students can learn from home.

However, the implementation of e-learning is not always smooth and effective. During the COVID-19 outbreak, schools and universities have rapidly implemented e-learning. Therefore, schools that have limited or no experience with e-learning and schools that have not prepared e-learning resources experience difficulties, especially, when teachers do not understand how to use online applications (Zaharah \& Kirilova, 2020).

The majority of studies on e-learning implementation barriers were conducted in normal situations (e.g., Assareh \& Bidokht, 2011; Hadijah \& Shalawati, 2017; Juliane, Arman, Sastramihardja, \& Supriana, 2017; Quadri, Muhammed, Sanober, Qureshi, \& Shah, 2017), where e-learning use is optional to enhance the teaching and learning process. Studies investigating e-learning use during pandemics are scarce (e.g.,Ash \& Davis, 2009). Most studies conducted do not focus on mathematics (e.g., Al-Harbi, 2011; Astri, 2017; Kabilan \& Khan, 2012). In addition, it seems that most studies on elearning barriers were conducted in the HEI context (e.g., Osman, 2018; Panda \& Mishra, 2007; Rabiee, Nazarian, \& Gharibshaeyan, 2013). This poses many challenges but at the same time highlights the importance of investigating e-learning barriers for mathematics teachers during pandemics.

This study was conducted in Indonesia where three prevailing challenges for mathematics teachers exist: First, Indonesian students consistently underperformed in international assessments (e.i., PISA and TIMSS) (Patahuddin, Suwarsono, \& Johar, 2018). Second, Indonesian mathematics teachers' content and pedagogical knowledge need improvement $(\mathrm{Ng}, 2011)$. Third, Indonesia has the fourth largest student population in the world consisting of 45.5 million students and 3.1 million teachers (Suryadarma \& Jones, 2013). Even though the country employs a decentralised education system, the central government still plays a major role in administering most educational policies such as curriculum and national exams. As one of the many education systems in the world that has implemented e-learning during the virus outbreak, it is important to investigate e-learning integration barriers from teachers' perspective.

The current study aims to investigate e-learning barriers experienced by Indonesian secondary mathematics teachers amid the COVID-19 pandemic. The study examines the relationship between each level of barriers as well as assesses differences in teachers' views on the barriers according to their demographic backgrounds. Findings from the present study will help to advance our understanding of e-learning integration barriers amid the COVID-19 pandemic in the context of developing countries at the secondary school level. Therefore, this study adds valuable insight to the elearning literature and provides important suggestions to improve e-learning practices. To achieve those aims, this study aspires to answer the following research questions:

1. What are the barriers that mathematics teachers view as significant to e-learning use during the COVID-19 pandemic?

2. What is the relationship between each level of barrier to e-learning use?

3. Are there any significant differences in teachers' views on barriers to e-learning use according to their backgrounds?

\section{RELATED LITERATURE AND CONCEPTUAL FRAMEWORK}

\section{What is a Barrier?}

e-learning integration in teaching and learning is a complex phenomenon; consequently, many teachers may encounter various difficulties or challenges. These difficulties are also known as 'barriers' (Schoepp, 2005). According to the Oxford Dictionary (2015), a barrier is "a fence or an obstacle that prevents movement or access". Furthermore, another definition of a barrier is offered by Schoepp (2005, p. 2), which is "any condition that makes it difficult to make progress or to achieve an objective". In this study, Schoepp's (2005) definition of the barrier was adapted. 
Table 1. Classification of barriers faced by teachers in using e-learning

\begin{tabular}{ll}
\hline Type of Barrier & Description \\
\hline School Level & Availability of software and hardware, internet, textbooks, school policy, time and technical support \\
Teacher Level & Confidence, knowledge, belief and experience \\
Curriculum Level & Structure of contents, assessment, e-learning resource that is in line with the curriculum \\
Student Level & Skill and knowledge, motivation, e-learning infrastructure \\
\hline
\end{tabular}

\section{Levels of E-Learning Integration Barriers}

Various classifications for e-learning integration barriers have been proposed. For instance, Ertmer (1999) identified two sets of barriers, namely first order and second order barriers. First order barriers include hardware, access, and technical support while the second order obstacles relate to pedagogy, belief or personal preferences. Pelgrum (2001) proposed two classifications for e-learning barriers: material and nonmaterial barriers. Material barriers refer to lack of Information and Communication Technologies (ICT) resources while non-material barriers relate to teachers' knowledge and skills. Balanskat, Blamire and Kefafa (2006) categorized barriers into teacher level, school level and system level.

Assareh and Bidokht (2011) classified e-learning barriers based on four areas they affect: learners, teachers, curriculum and schools. e-learning barriers related to learners include financial problems, motivation, assessment, isolation from peers, inadequate e-learning skills and experience, affection and social domain. Teachers e-learning barriers consist of various aspects such as knowledge limitations and assessment challenges. Regarding e-learning curriculum barriers, they encompass ambiguity, quality, resources, teaching process, and evaluation. Finally, barriers faced by schools comprise organizational and structural factors.

Quadri et al. (2017) investigated barriers affecting elearning implementation. They classified barriers into four areas: students, instructors, infrastructure and technology, and institutional management. The study reported that the most significant barrier is infrastructure and technology while the least significant is students. Their study showed that limited time to develop e-learning was the most significant factor that hinders e-learning implementation, whilst lack of students' ICT skills is the least significant factor.

Hadija and Shalawati (2017) investigated barriers that teachers encountered when using e-learning. Lack of time to prepare a lesson using technology was a major challenge that teachers experienced. Other important limitations were lack of adequate professional development concerning technology, limited physical resources, inadequacy of resources, limited access to technology, lack of technical support, competence and confidence.

In this study, we classified e-learning integration barriers based on Assareh and Bidokht (2011) classification, namely, teachers, schools, curriculum, and students. The barriers in terms of teacher level barrier included: lack of teacher confidence (Balanskat et al., 2006; Bingimlas, 2009; Scrimshaw, 2004); teachers' unwillingness to change their practice (Hew \& Brush, 2007; Scrimshaw, 2004); teachers' lack of understanding of e-learning advantages (Scrimshaw, 2004); teachers' attitudes and beliefs to ICT (Ertmer, 1999; Hew \& Brush, 2007); and teachers' knowledge and experience (Bingimlas, 2009; Marwan, 2008; Scrimshaw, 2004).

School-level barriers relate predominantly to hardware and software availability, access to internet connection and school policy. Teachers considered time to prepare lessons, textbooks and lack of technical support as major barriers (Bingimlas, 2009). Moreover, curriculum barriers include mismatch between students' assessments and e-learning (Hew \& Brush, 2007). Another issue is that curriculum may not support technology-based application (Hew \& Brush, 2007). Regarding student level barrier, this included students' inadequate e-learning skills (Assareh \& Bidokht, 2011), student's lack access to technology infrastructure and internet connection, and students' lack of motivation to use e-learning. The classification of barriers in the present study is presented in Table 1.

As we can see from the literature, barriers to elearning can include a number of both material and nonmaterial issues. Technology and internet accessibility and lack of an e-learning curriculum and assessment tools to effectively evaluate student growth limit what teachers can teach. Motivation in learning online, confidence in using e-learning technology, and teachers' attitudes to online instruction impact how and if learners will learn. All these barriers need to be considered when faced with an event such as a pandemic that forces teachers and students to immediately adjust to a different mode of teaching and learning.

\section{METHOD}

\section{Research Design}

In this study, a quantitative approach was followed using a cross-sectional questionnaire (Fraenkel, Wallen, \& Hyun, 2011). According to Fraenkel et al. (2011) quantitative methods are considered capable of providing reliable, valid, objective and generalizable findings. Moreover, questionnaires, one of most widely used quantitative instruments, may be administered to a large number of participants. If the researcher collects 
Table 2. Demographic Background of participants

\begin{tabular}{llcc}
\hline Demographic Background & & Number of Participants & Percentage \\
\hline Gender & Male & 83 & $52.2 \%$ \\
& Female & 76 & $47.8 \%$ \\
\hline Level of Education & Undergraduate Degree & 140 & $88.1 \%$ \\
& Postgraduate Degree & 19 & $11.9 \%$ \\
\hline Teaching Experience & $0-5$ Years & 32 & $20.1 \%$ \\
& 6-10 Years & 58 & $36.5 \%$ \\
& $11-15$ Years & 47 & $29.6 \%$ \\
& $16-20$ Years & 13 & $8.2 \%$ \\
Teacher Certification & More than 20 Years & 9 & $5.7 \%$ \\
& Yes & 115 & $72.3 \%$ \\
\hline
\end{tabular}

Table 3. Devices and Internet connection used for e-learning

\begin{tabular}{llcc}
\hline Devices for e-learning activities Type of Internet Connection & Number of Participants & Percentage \\
\hline Device & Mobile/Handheld Device & 81 & $50.9 \%$ \\
\multirow{3}{*}{ Internet Connection } & Computer/laptop & 78 & $49.1 \%$ \\
& Mobile Phone & 136 & $85.5 \%$ \\
& Landline Connection & 20 & $12.6 \%$ \\
& Modem & 3 & $1.9 \%$ \\
\hline
\end{tabular}

data based on a representative sample of the population, generalisations can be made about the whole population (Fraenkel et al., 2011).

\section{Participants}

Random sampling was employed in this study. The sample consisted of 159 participants (83 male and 76 female) who were upper and lower secondary mathematics teachers.

Moreover, the majority of participants had undergraduate degrees in mathematics education $(88.1 \%)$, whilst the remaining had post-graduate degrees $(11.9 \%)$. Most of the participants had more than 6 years of teaching experience $(79.9 \%)$ and most of them $(72.3 \%)$ had been certificated as professional teachers by the Indonesian Ministry of Education. Further details of participants' demographic information are presented in Table 2.

Nearly half of the participants (49.1\%) used a computer/laptop for e-learning whilst the remaining used mobile/handheld devices. Furthermore, the majority of participants $(85.5 \%)$ used mobile phones for internet connection and the rest used landline connections (12.6\%) and Modems (1.9\%).

\section{Research Instruments}

The questionnaire used was based on a conceptual framework developed specifically for this study. It consists of four scales, namely school level barrier, teacher level barrier, student level barrier and curriculum level barriers. To validate the questionnaire, we used convergent and divergent validation methods. Moreover, in terms of reliability, we utilized composite reliability and variance extracted value.
Table 4. Cronbach's alpha coefficient of the questionnaire constructs

\begin{tabular}{lc}
\hline Construct & Cronbach's Alpha Coefficient \\
\hline Teacher Level Barrier & .843 \\
School Level Barrier & .775 \\
Curriculum Level Barrier & .784 \\
Student Level Barrier & .816 \\
Total & .846 \\
\hline
\end{tabular}

Cronbach's alpha was calculated to assess reliability and it was .846 , which indicates that all items exhibit high levels of reliability and measure the same concept. Table 4 presents Cronbach's alpha coefficient of multi constructs that indicate adequate reliability.

\section{Data Collection and Data Sources}

An online questionnaire was used to collect data. A crucial reason for using an online questionnaire was compatibility with teachers' online work during the pandemic. Moreover, the online questionnaire was also easy to be administered and accessed using various devices (Fraenkel et al., 2011). The questionnaires were distributed after schools had been closed and the participants had been requested to use e-learning methods. The majority of participants were approached through WhatsApp groups and Indonesian teacher mailing lists, with a few teachers being approached through personal email. Participants were sent a link to a questionnaire hosted on Survey Monkey, an online questionnaire tool, and they were offered a chance to win USD20 vouchers as an incentive. The questionnaire was open for three weeks. 
Table 5. Guidelines for the interpretation of a correlation coefficient (Cohen, 1992)

\begin{tabular}{llc}
\hline Strength of & \multicolumn{2}{c}{ Correlation coefficient value } \\
\cline { 2 - 3 } Association & Negative & Positive \\
\hline Weak & -.3 to -.1 & .1 to .3 \\
Moderate & -.5 to -.3 & .3 to .5 \\
Strong & -.9 to -.5 & .5 to .9 \\
Very Strong & -1 to -.9 & .9 to 1.0 \\
\hline
\end{tabular}

\section{Data Analysis}

All responses on teachers' level barriers were coded on a 5-point scale. Descriptive and inferential statistical analysis were employed to answer the research questions. Regarding descriptive analysis, a mean and standard deviations of responses for all the items of barrier were calculated and presented in tables. For inferential statistical analysis, a repeated measure of ANOVA was employed to examine significant differences in barrier across the categories. Furthermore, an independent t-test and ANOVA were employed to examine difference in barrier according the participants' demographic background. Spearman correlation coefficients were calculated to assess relationships between barriers across the levels, and Cohen (1992) guidelines for the interpretation of a correlation coefficient was used to interpreted the correlation.

\section{RESULTS}

This section presents a descriptive result of the barriers and it is followed by a presentation of the results of repeated measure analysis. This section also presents results from Pearson Correlation analysis as well as the independent $\mathrm{t}$ - test and ANOVA test.

\section{Teacher E-learning Use Barriers}

As mentioned earlier, barriers were divided into four categories, namely teacher, school, curriculum and student barrier. The results are presented in Table 6 .

Regarding the teacher level barrier, the results showed lack of teachers' knowledge as the top barrier (mean =3.0) and lack of confidence ranked second (mean $=2.9$ ). Furthermore, teachers' bad experience with elearning (mean $=2.8$ ) and the convenience of e-learning use (mean $=2.7$ ) ranked third and fourth respectively, whilst their beliefs about e-learning (mean $=2.6$ ) was the lowest barrier in teacher level barriers.

In terms of the school level barriers, the result revealed that the top two barriers were lack of e-learning systems (mean $=3.5)$ and not having internet connection (mean $=3.5)$. Furthermore, lack of technical support (mean $=3.1$ ) and incompatibility of textbooks with elearning $($ mean $=3.1$ ) ranked second and third respectively. In addition, schools' regulations (mean = 2.8) and teachers' time for preparing e-learning materials

Table 6. Descriptive results of e-learning implementation barriers

\begin{tabular}{|c|c|c|c|}
\hline Construct & $\mathbf{N}$ & Mean & St Dev \\
\hline \multicolumn{4}{|l|}{ Teacher Level barrier } \\
\hline I do not have sufficient knowledge and skill to use e-learning during the Covid-19 pandemic & 158 & 3.0 & 1.05 \\
\hline I am not confident in using e-learning during the Covid-19 pandemic & 158 & 2.9 & 1.05 \\
\hline I have experience in using e-learning & 158 & 2.8 & 1.03 \\
\hline I believe that the use of e-learning in teaching is not useful during this pandemic & 158 & 2.6 & 1.07 \\
\hline The use of E-learning during this pandemic is not convenient for me & 158 & 2.7 & 1.09 \\
\hline \multicolumn{4}{|l|}{ School Level Barrier } \\
\hline My school does not have an e-learning system & 158 & 3.5 & 1.01 \\
\hline My school does not have internet connection & 158 & 3.5 & 1.16 \\
\hline School regulations do not support the use of e-learning during the Covid-19 pandemic & 158 & 2.8 & 1.07 \\
\hline Textbooks are not in line with e-learning use & 158 & 3.0 & 1.00 \\
\hline My school does not provide technical support for e-learning use & 158 & 3.1 & 1.05 \\
\hline Because of workload, I do not have enough time to prepare e-learning materials & 158 & 2.8 & 1.03 \\
\hline Curriculum Level Barrier & 158 & & \\
\hline $\begin{array}{l}\text { Learning and teaching resources that are available on the e-learning system are not in accordance } \\
\text { with the curriculum }\end{array}$ & 158 & 2.9 & 0.87 \\
\hline Schools require students' assessments that are not in line with e-learning use & 158 & 2.9 & 0.91 \\
\hline The contents of my subject cannot be taught using e-learning & 158 & 2.8 & 0.89 \\
\hline The contents of my subject are difficult to be taught using e-learning & 158 & 2.9 & 0.93 \\
\hline The contents of my subject are difficult to be understood by students through e-learning & 158 & 3.0 & 0.96 \\
\hline Student Level Barrier & 158 & & \\
\hline My students do not have sufficient knowledge and skill in the use of e-learning & 158 & 3.6 & 0.86 \\
\hline My students do not have devices (i.e. laptop and tablet) for the use of e-learning & 158 & 3.6 & 0.91 \\
\hline My students are not interested in using e-learning & 158 & 3.1 & 0.79 \\
\hline My students do not have internet connection & 158 & 3.5 & 1.01 \\
\hline My students are not able to access the e-learning system & 158 & 3.4 & 0.92 \\
\hline
\end{tabular}


Table 7. Summary of barriers at each level

\begin{tabular}{lccc}
\hline Construct & Mean & Std. Deviation & $\mathrm{N}$ \\
\hline Teacher Level Barrier & 2.78 & .9548 & 158 \\
School Level Barrier & 3.04 & .8546 & 158 \\
Curriculum Level Barrier & 2.94 & .8217 & 158 \\
Student Level Barrier & 3.47 & .7560 & 158 \\
\hline
\end{tabular}

Table 8. Summary of correlation matrix

\begin{tabular}{lcccc}
\hline & Teacher Level Barrier & School Level Barrier & Curriculum Level Barrier & Student Level Barrier \\
\hline Teacher Level Barrier & 1.00 & & & \\
School Level Barrier & $.556^{* *}$ & 1.00 & 1.00 & \\
Curriculum Level Barrier & $.572^{* *}$ & $.669^{* *}$ & $.579^{* *}$ & 1.00 \\
Student Level Barrier & $.468^{* *}$ & $.652^{* *}$ &
\end{tabular}

Correlation is significant at the 0.01 level (2-tailed)

Table 9. Results of Independent t-test

\begin{tabular}{ll}
\hline Teacher Background & Results \\
\hline Gender & Mean (Male $=3.11 ;$ Female $=2.99)$, Sig. $=.077 . \mathrm{df}=155.859, \mathrm{t}=1.124$ \\
Education Level & Mean (Undergraduate $=3.08 ;$ Post-graduate $=2.85)$, Sig. $=.693, \mathrm{df}=23.215, \mathrm{t}=1.336$ \\
Certification & Mean (Certificated $=2.99 ;$ Non-Certificated $=3.20)$, Sig. $=.841, \mathrm{df}=71.162, \mathrm{t}=-1.583$ \\
\hline
\end{tabular}

(mean $=2.8)$ were the least significant barriers in the school level.

Results of the curriculum level barriers showed that the top barrier was the difficulty faced by students to understand the content through e-learning (mean $=3.0$ ). This was followed by mismatch between e-learning and the curriculum (mean = 2.9), mismatch between requirements of assessment and e-learning (mean $=2.9$ ) and difficulty to teach content through e-learning (mean = 2.9).

At the student level barriers, the two top barriers were students' lack of e-learning knowledge (mean 3.6) and students' lack of access to a computer/laptop (mean=3.6). Moreover, students' lack of internet connection (mean $=3.5$ ) and lack of access to e-learning (mean $=3.5$ ) were ranked second and third respectively, whilst the lowest barrier was students' lack interest in elearning.

Table 7 summarizes e-learning barriers at each level. The results revealed that the most significant e-learning barrier was at the student level (mean=3.47). Moreover, the school level barrier (mean=3.04) and the curriculum level barrier (mean=2.94) came second and third respectively. The lowest barrier was the teacher level barrier (mean=2.78).

As mentioned previously, a repeated measure of ANOVA was used to examine if there was a significant statistical difference of factors within each level barrier. Mauchly's test indicated that the assumption of sphericity had been violated; therefore, degree of freedom was corrected using Huynh-Feldt estimate of sphericity. The results show that there were significant differences in teachers' view on e-learning barriers in across the level, $F(2.754,432.362)=14.90, \mathrm{p}<0.05)$. Therefore, we can conclude that the student level barrier was the most significant barrier faced by the Indonesian secondary mathematics teacher in the use of e-learning during COVID-19 outbreak.

\section{Correlation between Each Level of the Barriers}

A Pearson product moment correlation coefficient was computed to assess correlation between categories of the barriers. As shown in Table 8, there were strong and moderate positive correlations across the levels. The strongest correlation was between the school level barriers and curriculum level barrier, $\mathrm{r}=.669$ and $\mathrm{p}=$ .000. Furthermore, the second strongest correlation was between the school level and student level barriers, $\mathrm{r}=$ .652 and $p=.000$. In addition, the third strongest correlation was between the student level and curriculum level barriers, $r=.579$ and $p=.000$.

\section{Teacher Level Barriers According to Their Background}

To assess differences in barriers according to teachers' backgrounds (Gender, level of Education, Certification) we performed an independent t-test, whilst One-Way ANOVA was administered to examine differences in barrier according to teachers' teaching experience. Results of the independent t-test is presented in Table 9 and the results of One-Way ANOVA is summarized in Table 10. 
Table 10. Results of ANOVA

Teacher Background Results

Teaching experience $\quad$ Mean $(0-5$ Years $=2.99 ; 6-10$ Years $=3.11 ; 11-15$ Years $=3.0 ; 16-20$ Years $=2.98 ;$ More than 20

Years $=3.11)$, Sig. $=.923 . \mathrm{df}$ between groups $=4, \mathrm{df}$ within groups $=154, \mathrm{~F}=.228$

The results showed that there were no significant differences in barriers between male teachers and female teachers $\left(t_{155.859}=1.124, p>.05\right)$. Furthermore, there was no a significant difference in barriers between teachers with an undergraduate degree and teachers with a postgraduate degree $\left(t_{23.315}=1.336, p>.05\right)$. In addition, there was no significant difference in barriers between certificated teachers and non-certificated teachers $\left(t_{71.162}\right.$ $=-1.583, p>.05)$.

The results showed that there was no statistically significant difference between groups of teaching experience as demonstrated by one-way ANOVA (F $(4,154)=.228, p=.923)$ and there was no statistically significant difference in barriers according to teachers' backgrounds.

\section{DISCUSSION}

This study examined mathematics teachers' views on e-learning use barriers during the COVID-19 pandemic, the relationship between each level of the barriers, and the differences in teachers' views according to their backgrounds. The findings show three important points of discussion.

First, this study suggests that the top e-learning implementation barrier was at the student level. This is evidenced by the fact that the majority of participants agreed that students did not have sufficient knowledge and skills in using of e-learning applications. Furthermore, most participants also agreed that their students lacked access to devices and internet connection for e-learning purposes. The present study contributes to the literature on the most significant barrier of e-learning use during school closure. As a developing country that has the fourth largest education system in the world, the findings of this study have implications not only for Indonesia but also for other developing countries that have experienced school closure and encourage e-learning use. The findings indicate that students were not well prepared for elearning use before this pandemic. Therefore, when it comes to this emergency, it is challenging for teachers to get their student ready for learning in an online environment. Existing work has predominantly focused on the e-learning integration barriers during the normal academic term when schools are open and students have been prepared (Assareh \& Bidokht, 2011; Hadijah \& Shalawati, 2017; Juliane et al., 2017; Quadri et al., 2017). We believe that this finding is novel given that the current situation is completely different to the normal school term. Furthermore, this study focuses on mathematics where e-learning is challenging due difficulty in explaining mathematical concepts online
(Frid, 2002). However, the participants think that impact of the mathematics curriculum barrier is less significant than the student barriers.

Second, this study suggests that there was a strong positive correlation between the student level barrier and the school level barrier as well as the curriculum level barrier. This strong correlation, to some extent, might explain why the student level became the top barrier of ICT integration in the classroom as it has been widely known that there was a strong correlation between school culture and students achievement (e.g., Demirtas, 2010; MacNeil, Prater, \& Busch, 2009). As a result, this finding indicates that, as one of the most important education stakeholders, schools need to play an important role to overcome students' difficulty in elearning use in this challenging time.

Third, this study revealed there are no differences in barriers according to teachers' demographic background. This finding highlights two important points. First, in terms of gender, the dominant of male teachers over female teachers in e-learning use is no longer valid (Mailizar, 2018). These findings contradict the idea that technology-related activities have been viewed as a 'male domain' (e.g., Markauskaite, 2006; Tezci, 2010; Vitanova, Atanasova-Pachemska, Iliev, \& Pachemska, 2015). Second, it is widely believed that more advanced teaching experience is important to develop the skills required for effective teaching. This common belief is not in line with teachers' views on elearning integration barriers as teachers with different levels of teaching experience expressed relatively similar views on the barriers.

\section{CONCLUDING REMARKS}

Overall, this investigation demonstrates that Indonesian secondary mathematics teachers faced a great challenge in using e-learning as a tool of instruction during school closures as a result of the COVID-19 pandemic. Their most significant barriers were at the student level including student lack of knowledge and skill in e-learning use, and their lack of access to devices and internet connection. Student barriers had a strong correlation with the barrier at the school level. This study expands the existing studies relating the e-learning use in secondary schools, particularly in aspect of barriers to e-learning use during the time of a pandemic. It implies that the current use of e-learning in Indonesia faces huge challenges that might result in students' failure to learn in this difficult time and even beyond. It is crucial to overcome these challenges faced by developing countries. As Kohn, Maier, and Thalmann (2010) argue, 
knowledge transfer with e-learning in developing countries often fails, resulting in students being left behind at a crucial time in their education cycle. The findings of this study suggests that policymakers, particularly schools, should establish comprehensive strategies that prepare students to use e-learning. These strategies might include providing students vouchers for internet connection as well as incremental training of the use of e-learning prior to a crisis such as a pandemic as a way of being proactive with student education. Given the reality of the internet world, students will likely have to learn one thing or another through e-learning at some point in their adult life, and giving them the skills now will help them as working adults in the future.

The present study is subject to two major limitations. First, although all participants self-reported that they were secondary school teachers, we were unable to verify their teaching registration as the questionnaire was conducted online. Second, the only participants in this study were teachers. We believe that students' voices are also crucial to be raised in this issue. Nevertheless, the findings of this study may serve as an alert to teachers, schools and policymakers about the barrier in the use of e-learning in this difficult time. Therefore, further research is important to raise students' voices on this issue to examine to what extent students' barriers of using e-learning hinders them from achieving their learning goals, and exploring their voice on how to overcome the challenges they face.

\section{ACKNOWLEDGEMENTS}

We would like to thank all participants involved in this study. We would also like to thank Realistic Mathematics Education Research Centre of Syiah Kuala University.

\section{REFERENCES}

Al-Harbi, K. A.-S. (2011). E-Learning in the Saudi tertiary education: Potential and challenges. Applied Computing and Informatics, 9(1), 31-46. https://doi.org/10.1016/j.aci.2010.03.002

Ash, K., \& Davis, M. R. (2009). E-Learning's Potential Scrutinized in Flu Crisis. Education Week, 28(31), 112.

Assareh, A., \& Bidokht, M. H. (2011). Barriers to eteaching and e-learning. Procedia Computer Science, 3, 791-795. https://doi.org/10.1016/j.procs.2010. 12.129

Astri, L. Y. (2017). Barrier factors that influence satisfaction of e-learning: a literature study. Advanced Science Letters, 23(4), 3767-3771.

Balanskat, A., Blamire, R., \& Kefala, S. (2006). The ICT impact report: A review of studies of ICT on schools in Europe: European Communities: Education and Culture.
Bingimlas, K. A. (2009). Barriers to the successful integration of ICT in teaching and learning environment: A review of the literature Eurasia Journal of Mathematics, Science and Technology Education, 5(3), 235-245. https://doi.org/10.12973/ ejmste/75275

Cohen, L. (1992). Power primer. Psychological Bulletin, 112(1), 155-159.

Demirtas, Z. (2010). The Effects of School Culture on Student Achievement. Egitim ve Bilim, 35(158), 3.

Dictionary, O. E. (Ed.) (2015). Oxford English Dictionary. Oxford: Oxford University Press.

Ertmer, P. A. (1999). Addressing first and second order barriers to change: Strategies for technology integration. ETRED, 7(4), 47-61.

Fraenkel, J. R., Wallen, N. E., \& Hyun, H. H. (2011). How to design and evaluate research in education: New York: McGraw-Hill Humanities/Social Sciences/Languages.

Frid, S. (2002). Engaging primary students in working mathematically within a virtual enrichment program. Mathematics Education Research Journal, 14(1), 60-79. https:/ / doi.org/10.1007/BF03217116

Hadijah, S., \& Shalawati, S. (2017). Investigating Teacher 'Barrier to ICT (Information Communication Technology) Integration in Teaching English at Senior High School in Pekanbaru. Proceedings of ISELT FBS Universitas Negeri Padang, 5, 302-310.

Hew, K. F., \& Brush, T. (2007). Integrating technology into K-12 teaching and learning: Current knowledge gaps and recommendation for future research Educational Technology Research and Development, 55, 223-252.

Huang, R., Liu, D., Tlili, A., Yang, J., \& Wang, H. (2020). Handbook on Facilitating Flexible Learning During Educational Disruption: The Chinese Experience in Maintaining Undisrupted Learning in COVID-19 Outbreak. Beijing: Smart Learning Institute of Beijing Normal University.

Juliane, C., Arman, A. A., Sastramihardja, H. S., \& Supriana, I. (2017). Digital Teaching Learning for Digital Native; Tantangan dan Peluang. Jurnal Ilmiah Rekayasa dan Manajemen Sistem Informasi, 3(2), 29-35.

Kabilan, M. K., \& Khan, M. A. (2012). Assessing preservice English language teachers' learning using eportfolios: Benefits, challenges and competencies gained. Computers \& Education, 58(4), 1007-1020. https:// doi.org/10.1016/j.compedu.2011.11.011

Kohn, T., Maier, R., \& Thalmann, S. (2010). Knowledge transfer with e-learning resources to developing countries: Barriers and adaptive solutions ELearning 2010 (pp. 15-29): Springer. 
MacNeil, A. J., Prater, D. L., \& Busch, S. (2009). The effects of school culture and climate on student achievement. International Journal of leadership in Education, 12(1), 73-84. https://doi.org/10.1080/ 13603120701576241

Mailizar. (2018). Investigating Indonesian teachers' knowledge and use of ICT in mathematics teaching. (PhD), University of Southampton, Southampton, UK.

Markauskaite, L. (2006). Gender issues in preservice teachers' training: ICT literacy and online learning. Australasian Journal of Educational Technology, 22(1).

Marwan, A. (2008). Teachers' Perception of teaching with computer technology: Reasons for use and barriers in usage. International Journal of Instructional Technology E Distance Learning, 5(6), 17.

$\mathrm{Ng}$, D. (2011). Indonesian primary teachers' mathematical knowledge for teaching geometry: implications for educational policy and teacher preparation programs. Asia-Pacific Journal of Teacher Education, 39(2), 151-164. https:/ / doi.org/10.1080/ 1359866X.2011.560648

Osman, G. (2018). Formal e-Learning in Arab Countries: Challenges and Opportunities. In B. Lockee \& M. Childress (Eds.), Learning, Design, and Technolog. Cham: Springer.

Panda, S., \& Mishra, S. (2007). E-Learning in a Mega Open University: Faculty attitude, barriers and motivators. Educational Media International, 44(4), 323-338. https://doi.org/10.1080/0952398070168 0854

Patahuddin, S., Suwarsono, S., \& Johar, R. (2018). INDONESIA: History and Perspective on Mathematics Education Mathematics and its Teaching in the Asia-Pacific Region (pp. 191-230): World Scientific Publishing Co. Pte Ltd.

Pelgrum, W. J. (2001). Obstacle to the integration of ICT in education: Results from a worldwide educational assessment Computer $\mathcal{E}$ Education, 37,
167-178. https://doi.org/10.1016/S0360-1315(01) $00045-8$

Quadri, N. N., Muhammed, A., Sanober, S., Qureshi, M. R. N., \& Shah, A. (2017). Barriers effecting successful implementation of e-learning in Saudi Arabian universities. International Journal of Emerging Technologies in Learning (iJET), 12(06), 94107. https:/ / doi.org/10.3991/ijet.v12i06.7003

Rabiee, A., Nazarian, Z., \& Gharibshaeyan, R. (2013). An explanation for internet use obstacles concerning elearning in Iran. The International Review of Research in Open and Distributed Learning, 14(3), 361-376. https://doi.org/10.19173/irrodl.v14i3.1412

Schoepp, K. (2005). Barriers to technology integration in a technology-rich environment. Learning and Teaching in Higher Education: Gulf Perspectives, 2(1), $1-24$.

Scrimshaw, R. (2004). How can innovative ICT practice be sustained and extended?. Paper presented at the Becta Research Conference.

Suryadarma, D., \& Jones, G. W. (2013). Education in Indonesia. Singapore: Institute of Southeast Asian Studies.

Tezci, E. (2010). Attitude and knowledge level of teachers in ICT use: the case of Turkish teachers. International Journal of Human Science, 7(2), 19-44.

Vitanova, V., Atanasova-Pachemska, T., Iliev, D., \& Pachemska, S. (2015). Factors affecting the development of ICT competencies of teachers in primary schools. Procedia-Social and Behavioral Sciences, 191, 1087-1094. https://doi.org/10.1016/ j.sbspro.2015.04.344

WHO. (2020). Coronavirus disease (COVID-19) pandemic. 2020, from https:/ / www.who.int/

Zaharah, Z., \& Kirilova, G. I. (2020). Impact of Corona Virus Outbreak Towards Teaching and Learning Activities in Indonesia. SALAM: Jurnal Sosial dan Budaya Syar-i, 7(3). https://doi.org/10.15408/ sjsbs.v7i3.15104

\section{http://www.ejmste.com}

